\title{
Chemical Screening of Urochloa humidicola: Methods for Characterizing Secondary Metabolites and Allelopathic Activity on Forage Legumes
}

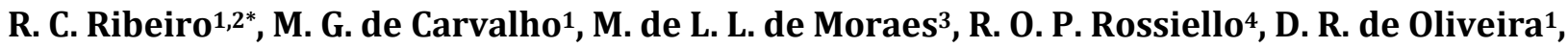 \\ R. M. Q. de Amorim³, E. Barbieri Junior ${ }^{2}$
}

${ }^{1}$ Phytochemistry Laboratory (PL), Department of Chemistry, Federal Rural University of Rio de Janeiro (UFRRJ), Seropédica-Rio de Janeiro, Brazil

${ }^{2}$ Instituto Federal de Educação, Ciência and Tecnologia de Mato Grosso (IFMT), Sorriso-MT, Brazil

${ }^{3}$ Department of Chemistry, Federal University of São Paulo (Universidade Federal de São Paulo-UNIFESP), Diadema-SP, Brazil ${ }^{4}$ Cultivated Plants Ecophysiology Laboratory, Department of Soils, Federal Rural University of Rio de Janeiro (UFRRJ), Seropédica-Rio de Janeiro

Email: *robertacristiane@gmail.com

\footnotetext{
How to cite this paper: Ribeiro, R.C., de Carvalho, M.G., de Moraes, M.D.L.L. Rossiello, R.O.P., de Oliveira, D.R., de Amorim, R.M.Q. and Barbieri Jr., E. (2018) Chemical Screening of Urochloa humidicola: Methods for Characterizing Secondary Metabolites and Allelopathic Activity on Forage Legumes. American Journal of Plant Sciences, 9, 1260-1278.

https://doi.org/10.4236/ajps.2018.96093
}

Received: March 15, 2018

Accepted: May 25, 2018

Published: May 28, 2018

Copyright (c) 2018 by authors and Scientific Research Publishing Inc. This work is licensed under the Creative Commons Attribution International License (CC BY 4.0). http://creativecommons.org/licenses/by/4.0/

\begin{abstract}
The aim of this study was to identify the main classes of secondary metabolites present in the root and shoot crude extracts and fractions from the forage grass Urochloa humidicola (Rendle) Morrone \& Zuloaga and to evaluate the allelopathic effect of these metabolites on forage legumes for intercropping. Phytochemical prospecting analyses, ${ }^{1} \mathrm{H}$ NMR and capillary electrophoresis were performed on extracts of $U$. humidicola. Allelopathic activity was evaluated in germination of Stylosanthes, Macrotyloma axillare and Lactuca sativa L. (standard) in the presence of crude extracts, isolated saponins, flavonoids and trans-cinnamic acid. The metabolite classes present in the extracts could be determined by the combined use of the tested analytical techniques, but their use alone was usually not sufficient to chemically characterize the species. Capillary electrophoresis was effective in detecting phenolic compounds. Macrotyloma axillare was tolerant to crude extracts of $U$. humidicola. Saponins and trans-cinnamic acid, but not the flavonoids, reduced germination of the target plants.
\end{abstract}

\section{Keywords}

Phenolic Compounds Legume-Forage Grasses Consortium, Capillary Electrophoresis, Macrotyloma axillare, Stylosanthes spp 


\section{Introduction}

Cattle milk and meat production systems in Brazil are almost exclusively based on native and cultivated pastures, which are the main source of animal feed [1], mostly due to their low production costs [2]. African grasses of the genus Brachiaria, recently renamed Urochloa [1], predominate in these pastures, occupying millions of hectares, especially in Central Brazil [3]. Urochloa humidicola (Rendle) Morrone \& Zuloaga is one of these grasses. It is widely used in areas with poorly drained and acidic soils, fire incidence, spittlebug attacks, and especially low nutrient availability, and it plays an important ecological role within pasture systems [4].

Despite its advantages, $U$. humidicola has low nutritional quality, with its crude protein $(\mathrm{CP})$ concentration being especially low. To increase the $\mathrm{CP}$ concentration, an alternative to chemical fertilizer application is intercropping with forage species of the Fabaceae family. However, some obstacles to intercropping remain particularly the slow establishment and low persistence of legumes in tropical pastures grasses. This is usually due to the morphological and physiological differences between grasses $\left(\mathrm{C}_{4}\right)$ and legumes $\left(\mathrm{C}_{3}\right)$, considering competition factors, as well as different growth rates [5].

Allelopathy is a phenomenon in which a plant (donor) may interfere, positively or negatively, with the germination and development of another plant (target) through the release of secondary or special metabolites (allelochemicals) [6] [7].

Knowledge about allelopathic effects between forage species is therefore important for adequate pasture management [8] being able to indicate legume species that are more tolerant to grass allelochemicals. Phenolic compounds [9], have being known to have allelopathic activity [10].

Although studies confirmed that $U$. humidicola, as well as other Brachiaria species, has allelopathic activity [11] [12], few reports exist of their effects on the tropical forage legumes used in mixed pastures. The aim of the present study was to evaluate the allelopathic effect of $U$. humidicola on the germination of Lactuca sativa L. (used as a standard for sensitivity) and the legumes Macrotyloma axillare and Stylosanthes ssp., both recommended for mixing with forage grasses, and to perform a phytochemical characterization of the shoot and root crude extracts of $U$. humidicola using phytochemical prospecting techniques, ${ }^{1} \mathrm{H}$ NMR and capillary electrophoresis.

\section{Materials and Methods}

\subsection{Plant Material Collection and Processing}

Shoots (S) and roots (R) of $U$. humidicola (donor plant) were collected in a pasture established for more than 25 years on Haplic Planosol in the Animal Sciences experimental area of the Federal Rural University of Rio de Janeiro (Universidade Federal Rural do Rio de Janeiro, UFRRJ), located in Seropédica, Rio de Janeiro, Brazil. Shoots (leaves and stems) were cut $0.05 \mathrm{~m}$ above ground 
level. At the sampling date, $U$. humidicola was in the vegetative stage. Roots were collected by direct digging, which was facilitated by the sandy-texture of the soil surface layer. Root samples were washed to remove adhered soil, according to [13]. All samplings were performed in the morning (07:00 a.m. local time), being the plant material sheltered in an isothermal box. In the laboratory the plant material was dried in a forced air oven for 72 hours at $45^{\circ} \mathrm{C}$ and ground into 1-mm particles (dust) using a Wiley mill. The samples were then subjected to exhaustive, successive and cold extraction, with solvents of increasing polarity. The first solvent was hexane $(\mathrm{H})$, followed by methanol $(\mathrm{M})$, methanol:water (7:3) (MW) and pure water (W). Each solvent remained in contact with the processed plant material for 7 days in glass containers. The process was repeated six times, until the material was exhausted. The solutions obtained were filtered by simple filtration, and the filtrates were concentrated by low pressure distillation using a rotary evaporator. The concentrates were placed in an $\mathrm{Ab}$ derhalden drying pistol or forced air oven at $30^{\circ} \mathrm{C}$ for complete drying and solvent removal. The resulting extracts are represented by the acronyms $\mathrm{BHSH}$, BHSM, BHSMW, BHSW, BHRH, BHRM, BHRMW and BHRW, where the letters are defined as follows: $\mathrm{BH}$ (U. humidicola), $\mathrm{R}$ (root), $\mathrm{S}$ (shoot), $\mathrm{H}$ (hexane), $\mathrm{M}$ (methanol), MW (methanol and water) and W (water).

\subsection{Fractionation of Crude Shoot Extracts}

The crude extracts were obtained, and the methanol shoot (BHSM) and root (BHRM) extracts were fractionated. Crude extract fractionation was performed by liquid-liquid partitioning in a separation funnel. Methanol extracts were solubilized in methanol: water (7:3) and fractionated using solvents of decreasing polarity: hexane $(\mathrm{H})$, dichloromethane (D), ethyl acetate (A) and butanol (B). The filtrate was collected and concentrated by vacuum distillation using a rotary evaporator.

\subsection{Analytical Methods}

Urochloa humidicola crude extracts were subjected to a series of chemical characterization reactions for the identification of different classes of secondary metabolites [14]: organic acids, reducing sugars, alkaloids, catechins, depside and depsidone, steroids and triterpenoids, flavonoids, cardiac glycosides, cyanogenicheterosides, quinones, saccharides, saponins, anthraquinones, tannins, sesquiterpenes and other lactones. Caffeic acid and sitosterol were used as standards for confirmation of the presence of cinnamic acid and steroid derivatives.

Chemical prospecting results were classified based on intensity as $(+++)$ large presence, $(++)$ notable presence, $(+)$ light presence and $(-)$ absence or inconclusive result. For some compounds, the results were confirmed by ${ }^{1} \mathrm{H}$ NMR. The ${ }^{1} \mathrm{H}$ NMR spectra were obtained using approximately $10 \mathrm{mg}$ of sample (crude extract) dissolved in solvent $\left(\mathrm{CDCl}_{3}, \mathrm{D}_{3} \mathrm{COD}\right.$ or $\left.\mathrm{D}_{3} \mathrm{CSOCD}_{3}\right)$ adjusted according to their polarity. Approximately $1 \mathrm{~mL}$ of each sample was placed in special glass 
tubes $(15 \times 5 \mathrm{~mm})$ and analysed using an NMR spectrometer (Bruker Advance), operating at a 400 or $500 \mathrm{MHz}$ resonance frequency for ${ }^{1} \mathrm{H}$, using a pulse sequence. Tetramethylsilane (TMS) was used as an internal reference standard for the frequency scales.

Urochloa humidicola crude extracts were analysed by capillary electrophoresis (CE) using a protocol for phenolic compounds [15]. The compounds were identified by comparing migration times and the UV/Vis spectra of sample peaks with appropriate standards. A standard mix containing five phenolic acids was used (caffeic, ferulic, o-benzoic, vanillic and chlorogenic acid) to confirm the compounds presence and identity. The analyses were performed using an MDQ CE system (Beckman Coulter, USA) equipped with a UV spectrophotometric detector and connected to a data-acquisition system. The detection wavelength was $214 \mathrm{~nm}$. Separations were performed using a fused-silica capillary (Polymicro Technologies, Phoenix, AZ, USA), with a $75 \mu \mathrm{m}$ internal diameter and a $60 \mathrm{~cm}$ total length and $52 \mathrm{~cm}$ effective length, at $25^{\circ} \mathrm{C}$ temperature. The samples and standards were injected by hydrodynamic injection $(0.5 \mathrm{psi} / 5 \mathrm{~s})$. The applied voltage was $20 \mathrm{kV}$, and the running electrolyte was $20 \mathrm{mM}$ sodium phosphate buffer, $\mathrm{pH}$ 6.7. Sodium phosphate stock solutions $(100 \mathrm{mM})$ were prepared in deionized water and refrigerated. The samples had been previously freeze dried and were dissolved in $5 \mathrm{~mL}$ of $95 \%$ ethanol. The resulting solutions were sonicated for $30 \mathrm{~min}, 5 \mathrm{~mL}$ of water was added $(5 \mathrm{mg} / \mathrm{mL})$, and the samples were filtered using a $0.22-\mu \mathrm{m}$ filter (Millex) in Falcon tubes and refrigerated. Before analysis, the samples were diluted in ethanol (1:1).

\subsection{Allelopathic Activity Bioassay}

The allelopathic activity of $U$. humidicola was assessed in the laboratory by evaluating its ability to inhibit or stimulate seed germination of target species in germination assays [16]. Lactuca sativa L. (lettuce), which is sensitive to secondary metabolites and commonly used as an indicator of allelopathic activity, was used as a target species [17]. The forage species tested were the tropical legumes Macrotyloma axillare (E. Mey.) Verdc. And Stylosanthes spp. O. Swartz (S. macrocephala M. B. Ferreira \& Sousa Costa and S. capitata Vog), which are recommended for intercropping with grasses in pastures. Legume seeds were obtained from EMBRAPA Agrobiology, located in Seropédica, Rio de Janeiro state, Brazil. Lettuce seeds were acquired from a reputable commercial company. All seeds were stored in a cold chamber at $\pm 5^{\circ} \mathrm{C}$ until being used in the germination assays.

Experiments were performed to evaluate the effect of the crude extracts of $U$. humidicola on germination of the tested legumes and L. sativa, and M. axillare was found to be the target species most tolerant to the crude extracts. Macrotyloma axillare and the standard species ( $L$. sativa) were then subjected to solutions containing the following:

1) Flavonoid mix (FM), which contained the flavonoids quercetin, rutin, kaempferol and kaempferol-3- $\alpha$-rhamnoside; flavonoid mix (FM) + trans-cinnamic 
acid (TCA); and pure trans-cinnamic acid TCA, at $2.5 \mathrm{mg} \cdot \mathrm{L}^{-1}$ each.

2) Saponin (S1), isolated from fraction 26 of BHRM-A (117 - 119); saponin

(S2), isolated from fraction 26 of BHRM-A (120 - 124); and pure hesperidin (flavonoid).

These solutions were tested indirectly to detect antagonisms or synergisms between the substances present in the $U$. humidicola extracts with an effect on the target species [18]. Hesperidin and the remaining flavonoids were tested because they presented similarities to the flavonoid isolated from root extracts of $U$. humidicola.

All tested substances were selected based on the detection of similar compounds in extracts of $U$. humidicola or based on previous reports.

Two saponin mixes were isolated from fraction 26, obtained by fractionation in ethyl acetate of the root methanolic extract: one from sub-fractions 117 - 119 (S1) and one from sub-fractions 120 - 124 (S2).

Seeds from the target species were selected and sterilized in $1 \%$ sodium hypochlorite. Seeds requiring dormancy breaking were treated as recommended by the Rules for Seed Analysis (Regra para Análise de Sementes-RAS).

Tests were performed using crude extract solutions at 1\% [10] and standard solutions at $5 \mathrm{mg} \cdot \mathrm{L}^{-1}[15]$.

All extracts were dissolved in distilled and deionized water, except for the hexane extracts, which were eluted with the same amount of dichloromethane, and for this reason, a control was used for this solvent. A control with application of pure water was established for each species for comparison of the germination response. Tests on the extracts in dichloromethane were performed in glass Petri dishes ( $9 \mathrm{~cm}$ diameter), and tests on the extracts in water were performed in transparent plastic Gerbox boxes $(11 \times 11 \times 3 \mathrm{~cm})$.

Three sheets of sterilized $\left(120^{\circ} \mathrm{C}\right)$ Whatman number 6 filter paper were placed in each container. Five millilitres of solution was added to each Gerbox and 3 $\mathrm{mL}$ to the Petri dishes. Twenty-five seeds were then placed in each container, per replicate and species. For extracts in dichloromethane, the seeds were placed after the solvent had evaporated. Four replicates were set for each treatment. Four replicates for each treatment were placed in a plastic bag in a germination chamber (BOD) for a period dependent on the target species. Germination time, temperature and photoperiod for each species were established as previously described [11].

Germination in response to crude extract application was analysed by counting the normal seedlings at two different times, chosen depending on the target plant. After being counted, the normal seedlings were removed from the containers, and the data were expressed in percent form [11].

\subsection{Statistical Analysis}

Germination data were expressed as a percentage (\%) and arcsen $(\sqrt{ } \% / 100)$-transformed to meet the normality assumption. After being processed, the data were analyzed using statistical procedures from SAS (Statistical Analysis 
System; [19]. Analysis of variance (ANOVA) was performed using GLM PROC. Means were compared using the Tukey test (5\%). A completely randomized experimental design was used, with four replicates.

\section{Results}

In the present study, phytochemical prospecting analyses were combined with ${ }^{1} \mathrm{H}$ NMR, a physical method of organic analysis, to confirm or negate the presence of classes of secondary metabolites detected chemically. In addition, capillary electrophoresis (CE) was used to determine phenolic acids.

Phytochemical prospecting of shoot (S) and root (R) crude extracts (Table 1) provided an overview of the chemical profile of the different plant parts of $U$. humidicola.

Although, in some cases, prospecting indicates the absence of certain metabolites, this does not mean that these metabolites cannot be detected by other analytical techniques. An example of this is alkaloids, which were detected with lower intensity than the remaining compounds. Flavonoids were not detected via phytochemical prospecting, but indications of their presence in extracts BHSMW and BHSW were detected using ${ }^{1} \mathrm{H}$ NMR. The use of NMR was therefore essential, not only for structural determination but also to complement the prospecting methods (Table 1).

Table 1. Phytochemical prospecting analyses (Prosp) with the aid with ${ }^{1} \mathrm{H}$ NMR of the crude extracts of the shoot $(\mathrm{S})$ and the root $(\mathrm{R})$ of $U$. humidicola.

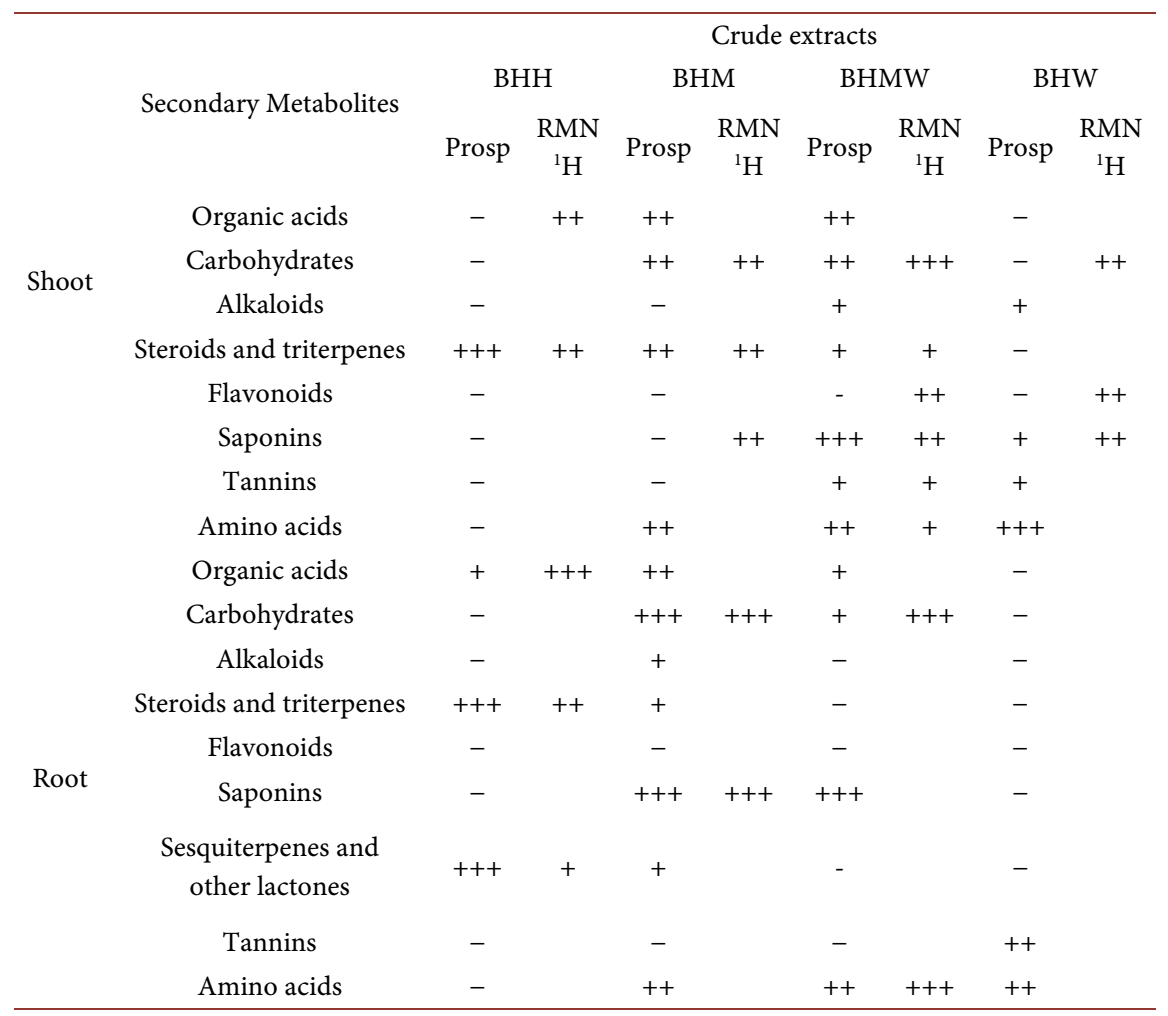

$(+++)$ large presence; $(++)$ notable presence; $(+)$ light presence and $(-)$ absence or inconclusive result. $\mathrm{BH}$ $=U$. humidicola $\mathrm{S}=$ Shoot; $\mathrm{H}=$ Hexano; $\mathrm{M}=$ Methanol; $\mathrm{MW}=$ Methanol water e $\mathrm{W}=$ water. 
Following fractionation of the shoot extracts of $U$. humidicola, a glycosylated flavonoid, which was mixed with some impurities, was identified by ${ }^{1} \mathrm{H}$ NMR spectral analysis of the ethyl acetate fraction (Figure 1(a) and Figure 1(c)).

Phytochemical prospecting revealed a low presence of alkaloids in the root extracts, namely, in the methanol extract. The presence of organic acids was confirmed in the roots in the hexane, methanol and methanol-water extracts (Table 1).

The presence of steroids in the crude hexane extracts was confirmed by the two techniques, both in the shoots and roots, except for BHSW, BHRMW and BHRW (Table 1). Sitosterol and stigmasterol were identified in BHRH (Figure 1(b)) by the ${ }^{1} \mathrm{H}$ NMR spectral analysis, mixed with a fatty acid.

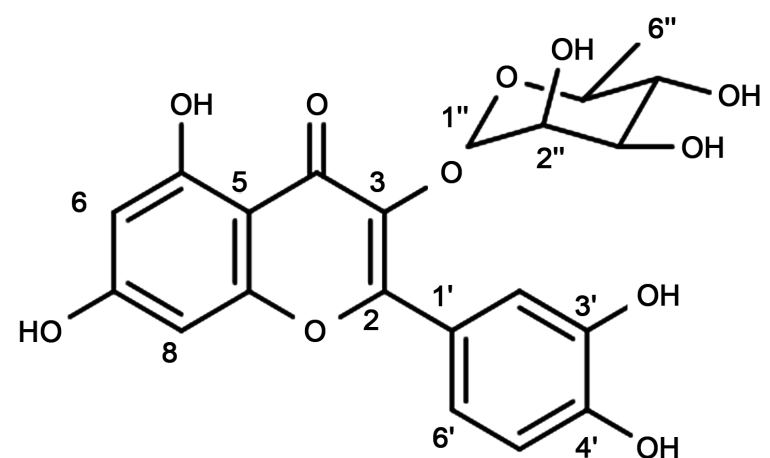

(a)

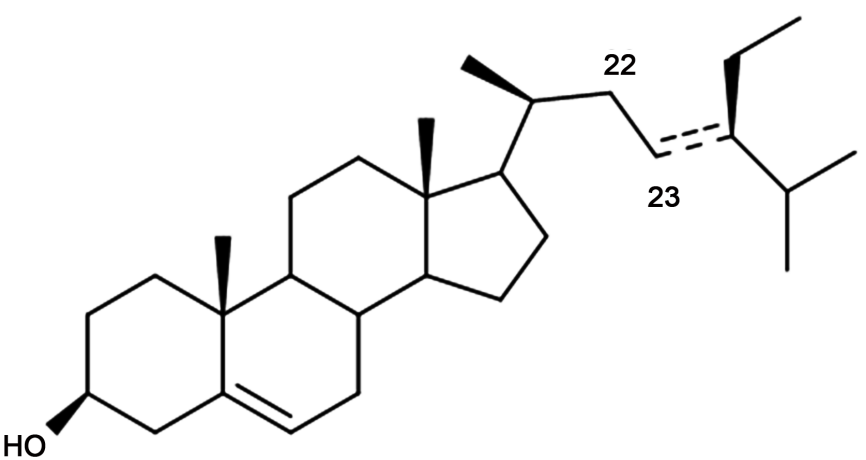

(b)

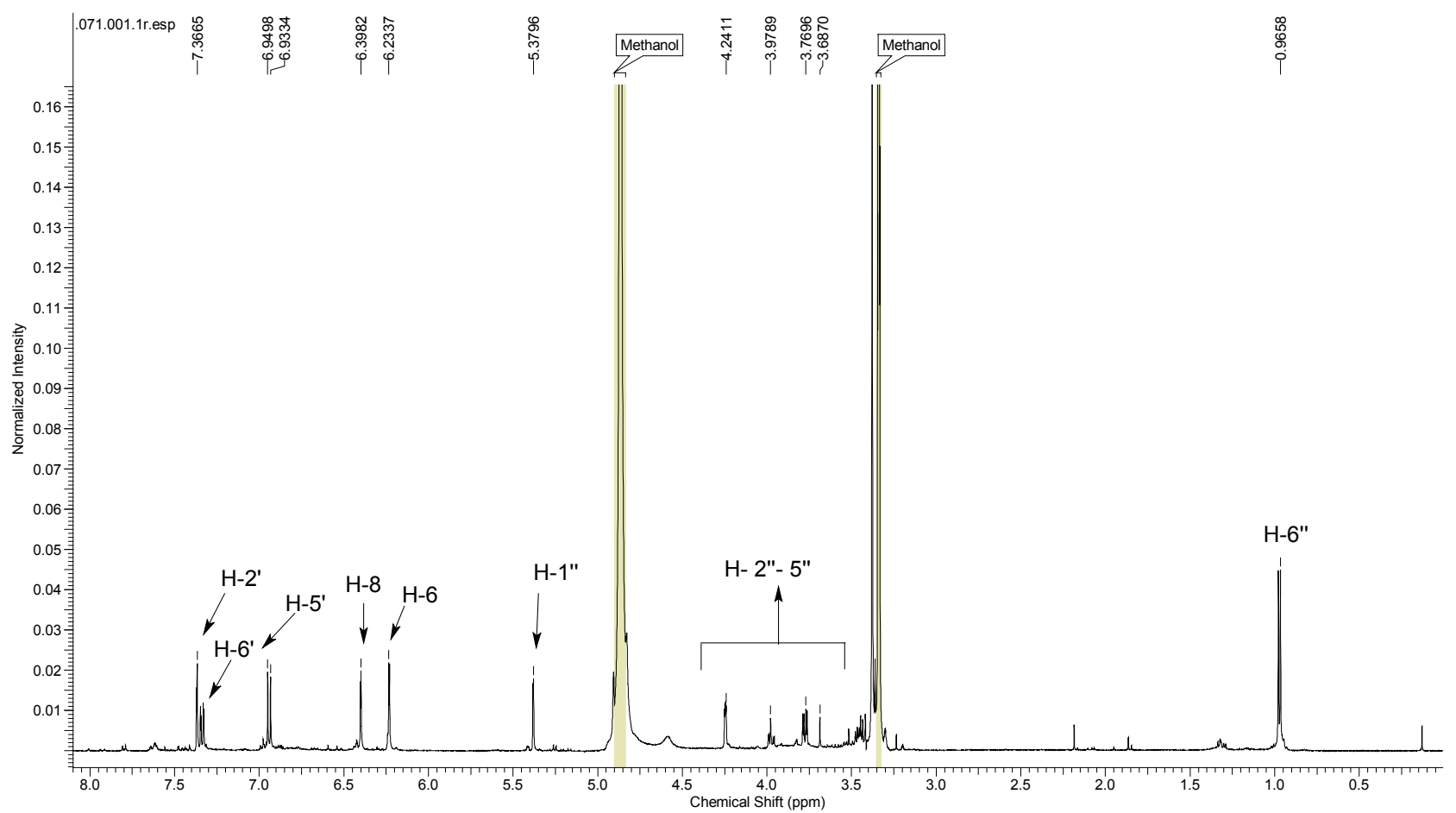

(c)

Figure 1. (a) Glycosylated flavonoid identified in the ethyl acetate fraction of shoot extracts of U. humidicola; (b) Stigmasterol $\left(\mathrm{D}^{22-23}\right)$ and sitosterol (22-23-dihydro) identified in the crude hexane root extract of $U$. humidicola; (c) $\mathrm{RMN}{ }^{1} \mathrm{H}$ do 5,7,3',4'-tretrahydroxy-3-O-rhamnopyranosil-flavone in the ethyl acetate fraction of shoot extracts of $U$. humidicola. 
A mix of saponins and flavonoid derivatives were identified by ${ }^{1} \mathrm{H}$ NMR spectral analysis and compared with the published data on ethyl acetate fractions of root methanol extracts, revealing a minimum of three components, including gitogenin derivatives (Figure 2(a) and Figure 2(b)). Identification of the chemical constituents by NMR indicated that saponins and flavonoid derivatives are major components of the shoots and roots of $U$. humidicola, respectively.

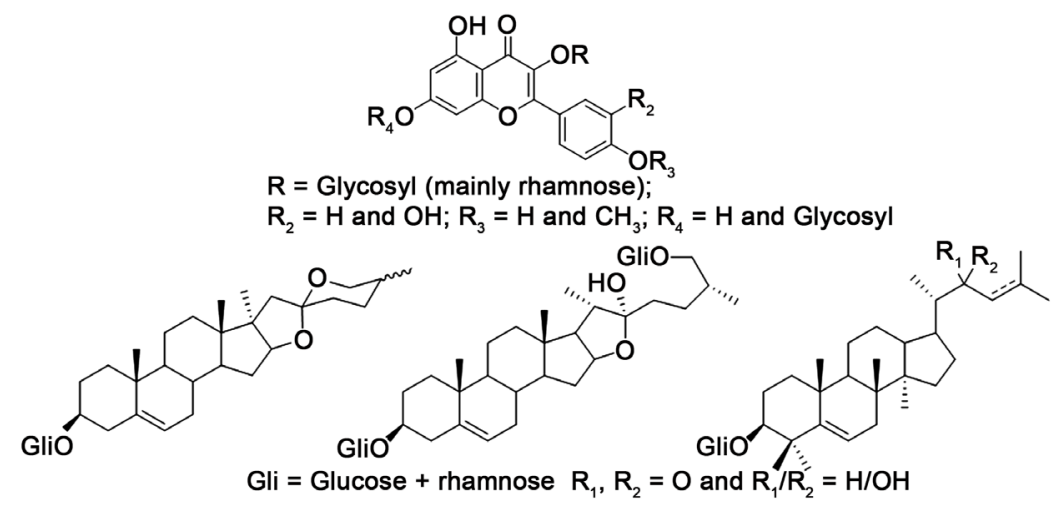

(a)

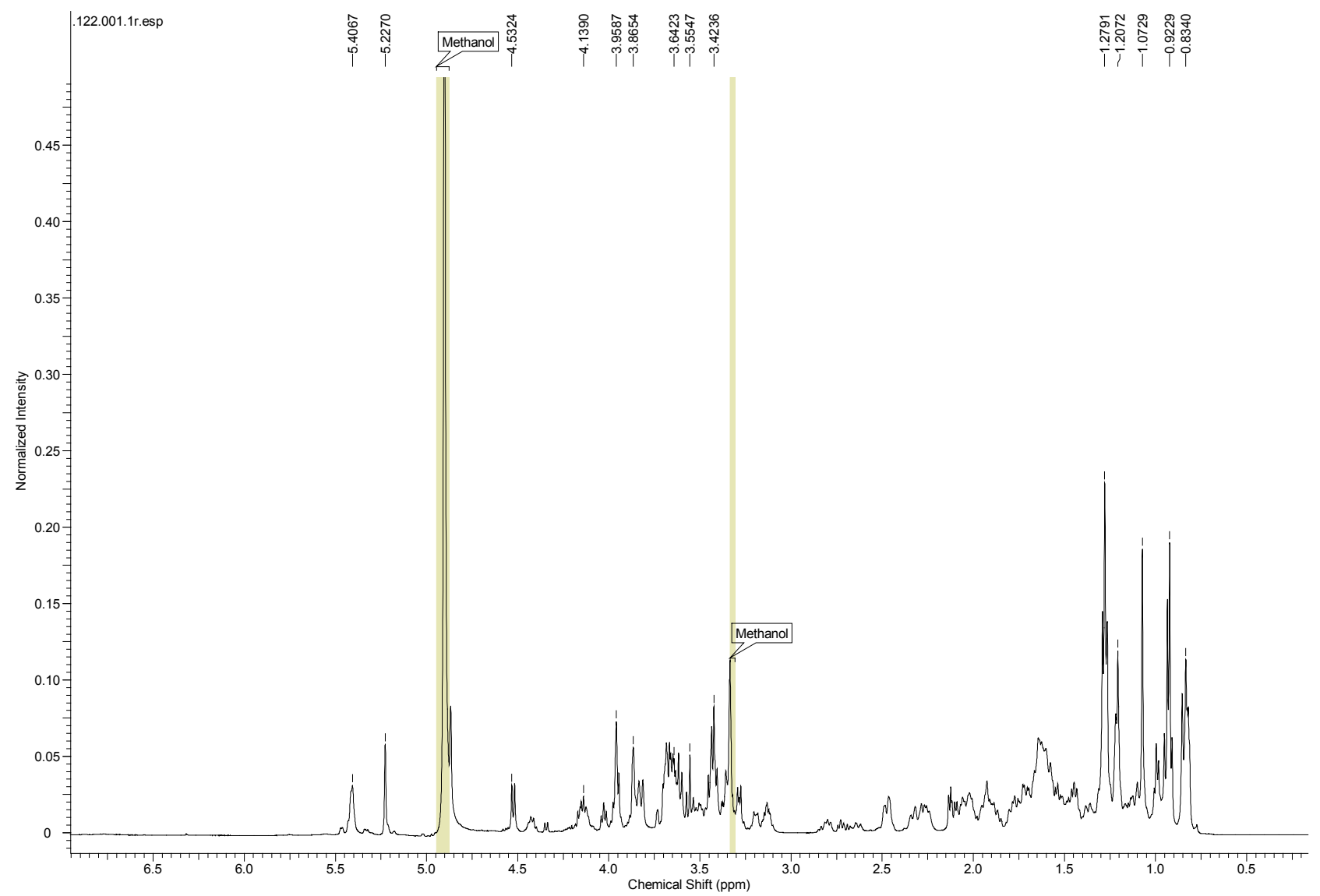

(b)

Figure 2. (a) Basic skeletons of flavonoids and saponins identified in ethyl acetate fractions obtained by partitioning of the methanol root extract of $U$. humidicola; (b) Spectrum of the ethyl acetate fraction of the methanolic extract partition of $U$. humidicola roots confirming the presence of saponins $\left(\mathrm{S}_{1}\right.$ and $\left.\mathrm{S}_{2}\right)$ in the plant. 
The presence of cinnamic acids and their derivatives was not accurately confirmed by phytochemical prospecting and NMR but was detected by capillary electrophoresis (CE). The analyses of the phenolic acid standards mix and crude shoot extract of $U$. humidicola are presented in Figure 3. The presence of phenolic acids in BHSM was confirmed, presenting intense signals.

The analyses of ethyl acetate, hexane and butanol shoot extracts are shown in Figure 4(a). Phenolic compounds were detected in the ethyl acetate fraction but not in the butanol and hexane fractions (BHSM-B and BHSM-H). Despite the low cinnamic acid concentration in the butanol fraction, flavonoids were detected by phytochemical prospecting and confirmed by NMR (Figure 4(b)).

The evaluation of the allelopathic effects of crude shoot extracts of $U$. humidicola on target plant species is presented in Figure 5. All extracts inhibited the germination of L. sativa, ( $<$ 0.05) (Figure 5(a)), indicating the presence of bioactive substances in crude shoot extracts of $U$. humidicola. Lactuca sativa is used as a standard target species in allelopathic tests. Also for L. sativa, significant differences $(\mathrm{p}<0.05)$ were observed between all treatments with extract application, except for BHSM and BHSMW. This was likely due to the similar classes of metabolites present in these two extracts, which can be observed in the phytochemical prospecting results (Table 1). Extract BHSW had a high inhibitory effect on $L$. sativa germination, resulting in complete inhibition of germination (100\%). For the target legume Stylosanthes ssp., significant differences $(\mathrm{p}<0.05)$ were observed between the extracts and the respective control treatments but not between the different extracts ( $p>0.05$; Figure 5(b)).

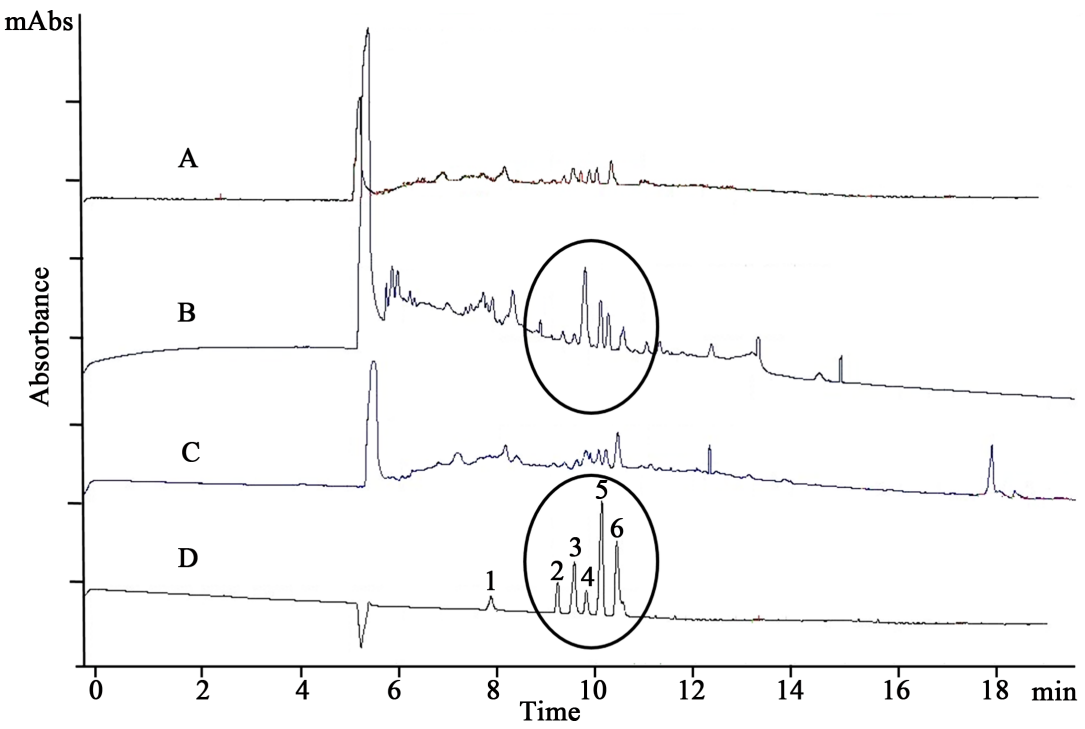

Figure 3. Electropherograms of fractions of extracts from shoot of $U$. humidicola, injected into the CE protocol for phenolic acids. Samples: A = BHSMW, B = BHSM, C = BHSW, and $\mathrm{D}=\mathrm{mix}$ of phenolic standards at $30 \mathrm{mg} \cdot \mathrm{L}^{-1}$. Peaks: 1-chlorogenic acid, 2-caffeic acid, 3-ferulic acid, 4-o-benzoic acid, 5-o-coumaric acid and 6-vanillic acid. Analysis conditions: $20 \mathrm{mM}$ sodium phosphate buffer $\mathrm{pH}$ 6.9, injection by pressure for 10 $\mathrm{s}$, voltage $+20 \mathrm{kV}$, direct UV detector at $214 \mathrm{~nm}$ and $25^{\circ} \mathrm{C}$. The circle marks the phenolic acids standards peaks and similar peaks in samples of $U$. humidicola. 


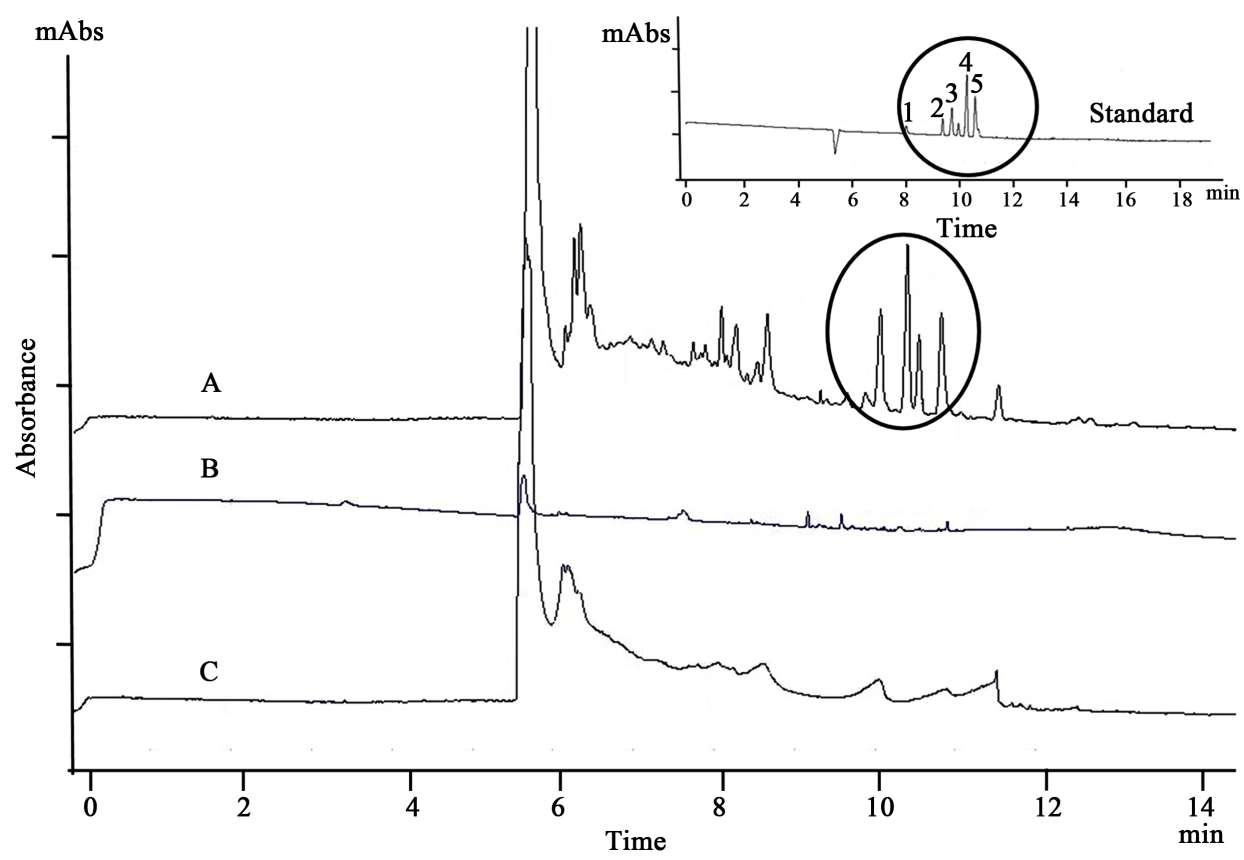

(a)

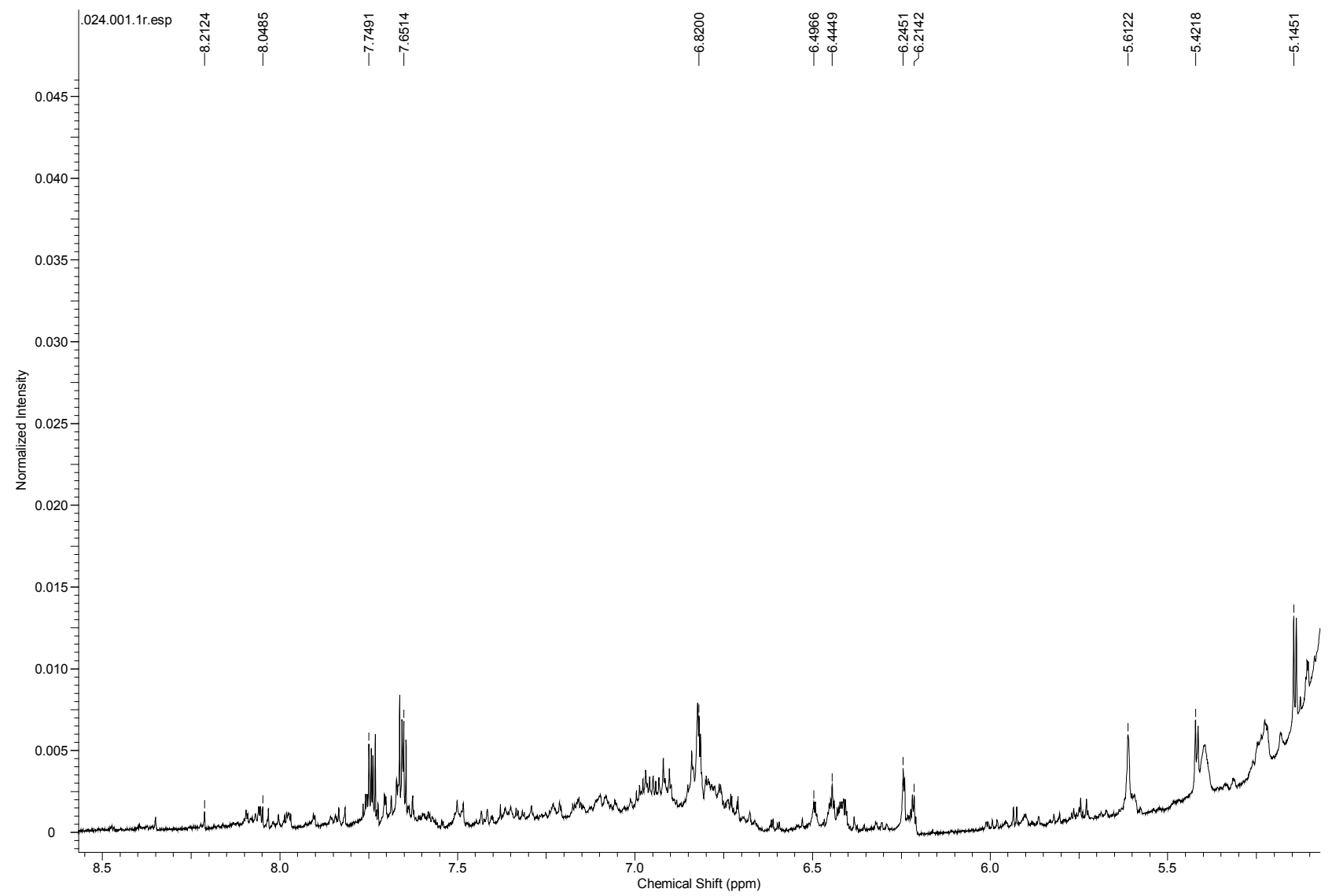

(b)

Figure 4. (a) Electropherograms of fractions of extracts from shoots-ethyl acetate; (b): BHSM-H-hexane and (c): BHSM-B-butanol. Peaks and analysis conditions: see Figure 3; (b) NMR spectrum demonstrating the characteristic signs of the presence of flavonoids in the butanolic fraction of the methanolic extract of the soil part of $U$. humidicola. 


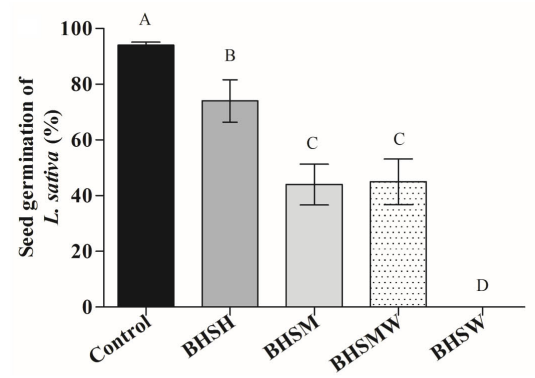

(a)

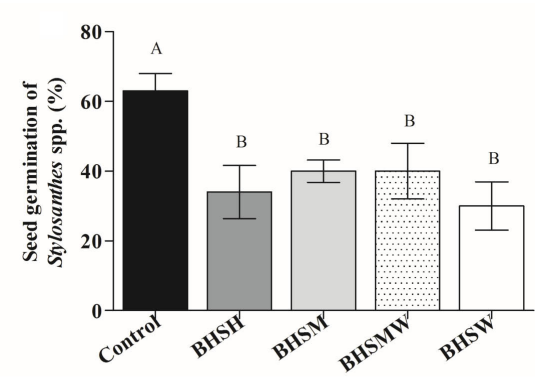

(b)

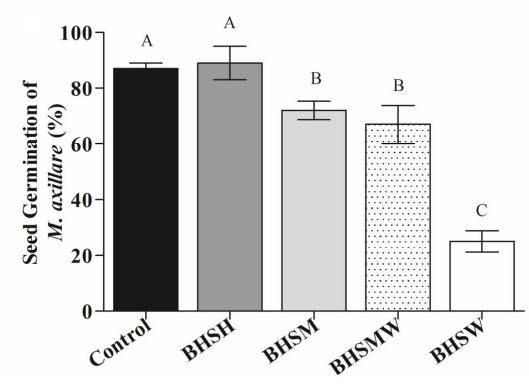

(c)

Figure 5. Allelopathic activity of crude shoot extracts of Urochloa humidicola on seeds of (a) Lactuca sativa (lettuce); (b) Stylosanthes spp.; and (c) Macrotyloma axillare. $\mathrm{BH}=U$. humidicola. $\mathrm{S}=$ shoot, $\mathrm{H}=$ hexane, $\mathrm{M}=$ methanol, $\mathrm{MW}=\mathrm{methanol} / \mathrm{water}$, and $\mathrm{W}=$ water. Different letters indicate significant differences according to the Tukey test $(\mathrm{p}<0.05)$.

At this point, it is interesting to compare the effects of the crude hexane extracts of shoots (Figure 5) and roots (Figure 7) on target species germination. BHSH had the least negative effect on the germination of $L$. sativa and no effect on the germination of $M$. axillare, whereas BHRH caused $100 \%$ inhibition of $L$. sativa and Stylosanthes, with no significant differences between $M$. axillare and the respective control. These results led to the investigation of the presence of cinnamic acids in BHSH and BHRH (Figure 6).

In contrast to that observed for crude shoot extracts (Figure 5), the inhibition of $L$. sativa germination decreased pronouncedly with increasing polarity of the root extracts (Figure 7(a)). Allelochemicals seem to predominate in these extracts, especially in the hexane and methanol fractions. The extracts BHRH and BHRM caused significant decreases in the germination (100\%) of L sativa. At the other extreme, BHRW application resulted in almost complete inhibition of germination when compared to the control treatment $(\mathrm{p}<0.05)$. Regarding the effect of the crude root extracts of $U$. humidicola on $M$. axillare germination, although significantly different, BHRW caused only slight inhibition of germination (Figure $7(\mathrm{c})$ ).

Based on the observed effects of the crude extracts and fractions of $U$. humidicola, assays were performed using pure substances indicated as allelopathic and substances belonging to the chemical groups detected in the samples: 1) trans-cinnamic acid (TCA), a phenolic compound; 2) a mix of four flavonoids (rutin, kaempferol, kaempferol 3- $\alpha$-rhamnoside and quercetin; FM); and 3) FM + TCA. These substances were chosen because of the large amount of information on the biological activity of phenols and flavonoids and because this group of compounds was confirmed to be present in some of the extracts evaluated.

The results of the germination of $L$. sativa and the forage legume $M$. axillare in response to the application of the described solutions are presented in Figure 8. TCA resulted in complete inhibition of the germination of $L$. sativa and FM in significantly lower germination than the control treatment, although the difference was slight (13\%). For $M$. axillare, the most pronounced decrease in germination was observed in response to the TCA treatment (17.5\%). Interestingly, the FM treatment resulted in no significant differences $(p>0.05)$ from the control. 
Although the isolation of secondary metabolites of $U$. humidicola was not the focus of the present study, concurrent studies were performed with this focus. Following fractionation of the methanol shoot extract with ethyl acetate (BHRM-A), a mix of saponins was isolated. The flavonoid hesperidin was also tested for comparison with the responses to S1 and S2 (saponin mixes). L. sativa and $M$. axillare were used in these tests (Figure 9).

For L. sativa, significant differences $(\mathrm{p}<0.05)$ were observed between the treatments and respective control. No significant differences $(p>0.05)$ were observed between the treatments with saponins, which resulted in the highest germination inhibitions, confirming their phytotoxic effect on these two plant species. Although less pronounced than observed for saponins, hesperidin also had a negative effect on the germination of lettuce seeds. $M$. axillare responses to the saponin mixes were very similar to those observed for L. sativa, but hesperidin

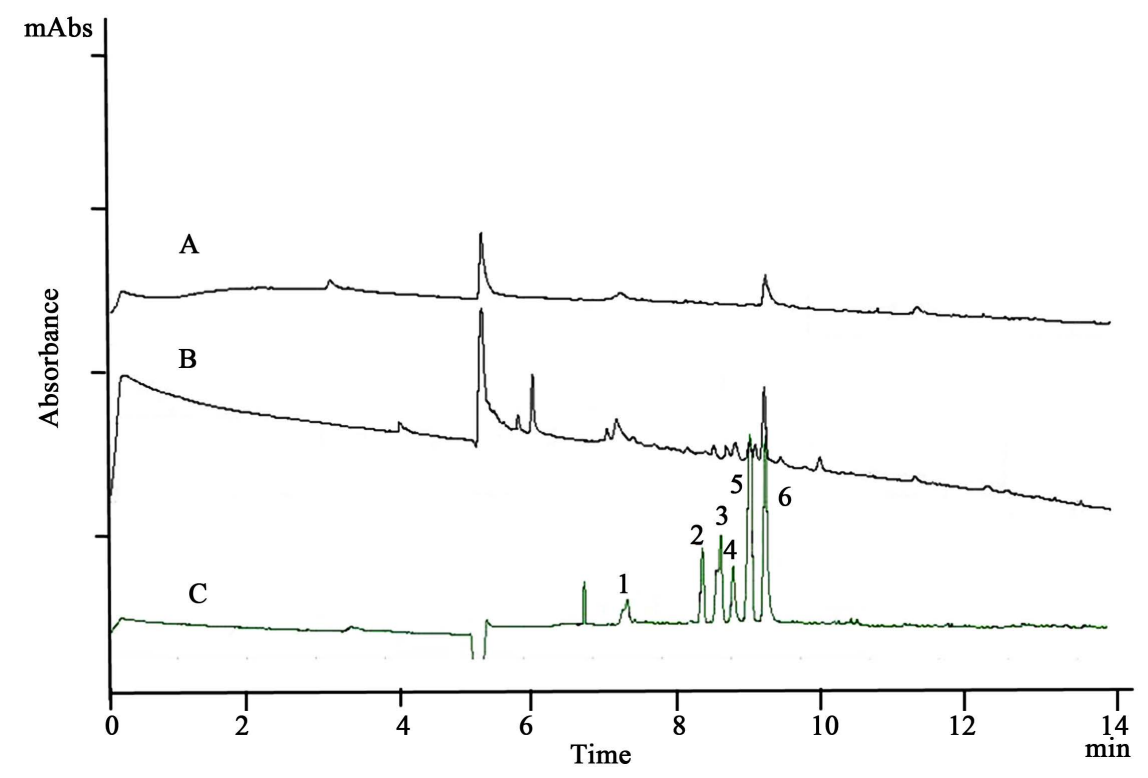

Figure 6. Electropherograms of crude hexane extracts of $U$. humidicola, injected in the CE protocol for phenolic acids. Samples: $\mathrm{A}=\mathrm{BHSH}$-shoot, $\mathrm{B}=\mathrm{BHRH}-$ root, and $\mathrm{C}=\mathrm{mix}$ of phenolic acid standards at $30 \mathrm{mg} \cdot \mathrm{L}^{-1}$. Peaks and analysis conditions: see Figure 3.

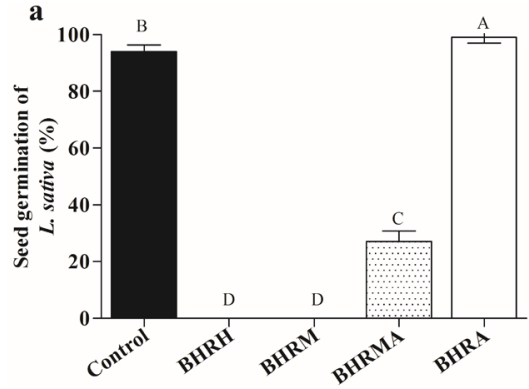

(a)

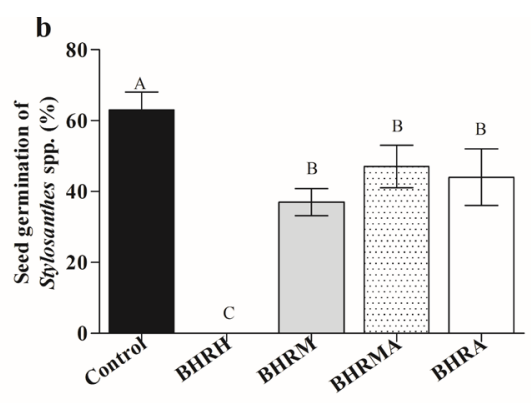

(b)

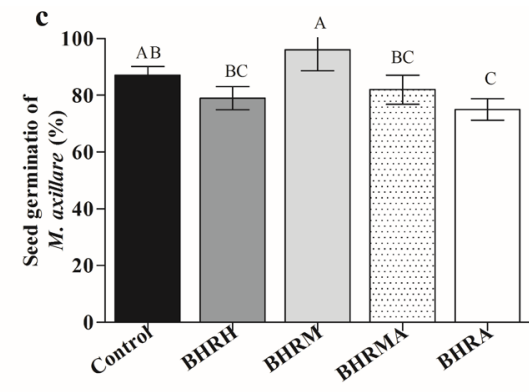

(c)

Figure 7. Allelopathic activity of crude root extracts of $U$. humidicola on seeds of (a) L. sativa (lettuce); (b) Stylosanthes spp; and (c) $M$. axillare $\mathrm{BH}=U$. humidicola, $\mathrm{R}=$ root $\mathrm{H}=$ hexane, $\mathrm{M}=$ methanol, $\mathrm{MW}=$ methanol/water, and $\mathrm{W}=$ water. Different letters indicate significant differences according to the Tukey test $(\mathrm{p}<0.05)$. 


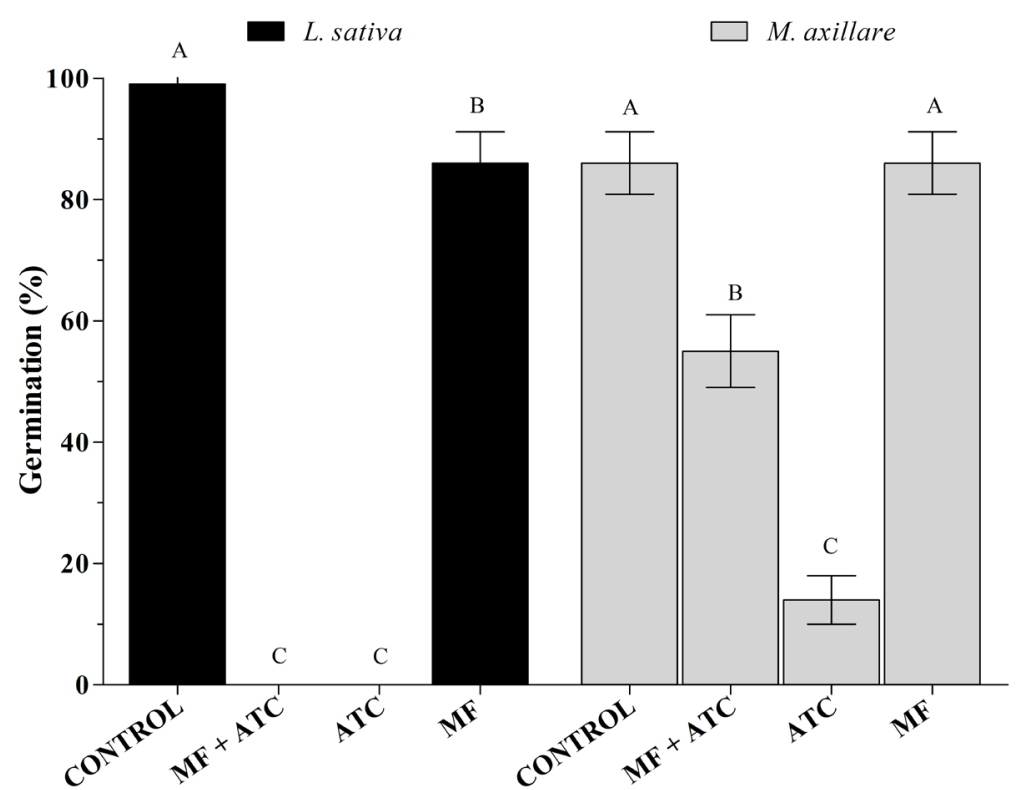

Figure 8. Allelopathic activity of 1 ) trans-cinnamic acid (TCA), phenolic compounds; 2) mix of four flavonoids (FM: rutin, kaempferol, kaempferol 3'- $\alpha$-rhamnoside and quercetin); and 3) FM + TCA, on L. sativa and the legume M. axillare. Different letters indicate significant differences according to the Tukey test $(\mathrm{p}<0.05)$.

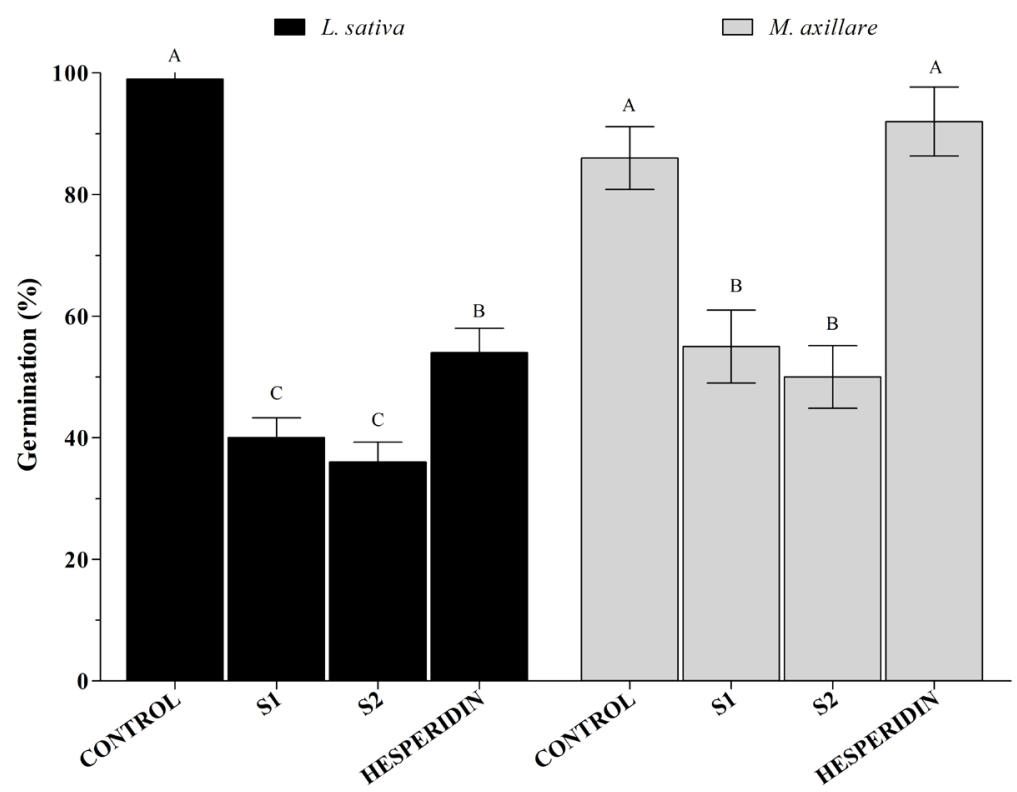

Figure 9. Allelopathic activity on L. sativa and M. axillare of S1 and S2, two saponin mixes obtained from the ethyl acetate fraction of the methanol extract of $U$. humidicola roots, and hesperidin (flavonoid). Different letters indicate significant differences according to the Tukey test $(\mathrm{p}<0.05)$.

resulted in similar responses to those observed for the flavonoid mix, not being significantly different from the respective controls $(\mathrm{p}>0.05)$ (Figure 8).

Both the HA and SNP treatments resulted in increased root GS activity compared to the control, increasing it by approximately $40 \%$ (Figure 2(b)). Five 
days after the beginning of the experiment, GS activity was higher for the low than for the high $\mathrm{N}-\mathrm{NO}_{3}^{-}$supply.

\section{Discussion}

Special metabolites have been previously isolated and identified for $U$. humidicola [12]. However, only one previous report was found that aimed at isolating, identifying and characterizing the allelopathic effect of chemical substances produced by $U$. humidicola [10]. In that study, p-coumaric acid was isolated from methanol-water crude extracts, identified by ${ }^{1} \mathrm{H}$ and ${ }^{13} \mathrm{C}$ NMR spectral analysis, and observed to have an allelopathic effect on weeds that cause damages to livestock farming. $p$-coumaric acid is a derivative of cinnamic acid, and no specific tests exist for the detection of these acids within phytochemical prospecting. However, they are organic acids and are detected as part of this class of metabolites. Because minor components may not be detected by ${ }^{1} \mathrm{H}$ and ${ }^{13} \mathrm{C}$ NMR, and chromatographic analysis is more sensitive and able to detect minor components, a microanalytical method was used (capillary electrophoresis) for the identification of phenolic acids. Phenolic, cinnamic, and benzoic acids and their derivatives were selected based on their importance in the literature and relevance in allelopathystudies [7] [20] [21].

The phenolic acids used as standards in the CE protocol for the detection of phenolic compounds were chosen based on reports of their participation in allelopathic phenomena [15].

Except for the hexane shoot and root extracts of $U$. humidicola, NMR analyses revealed no characteristic signals of phenolic acids that confirmed their presence. An example of this would be doublets $(\mathrm{H}-\alpha / \mathrm{H} \beta)$ with a coupling constant of approximately $15 \mathrm{~Hz}$, typical of trans-cinnamic systems. Taking all the data together, interestingly, the presence of organic acids, which may include phenols, was detected by phytochemical prospecting in BHSM, BHSMW, BHRM and BHRMW and, with lower intensity, in BHRH (Table 1). CE resulted in a similar detection of organic acids (prospecting) and phenol standards (cinnamic acids; CA). Because organic acids were more detected in shoots, especially in BHSM, and previous reports showed that allelochemicals are usually isolated from leaves [22], the fractions of the crude shoot extracts of $U$. humidicola were also subjected to CE.

Although it was not detected by phytochemical prospecting and was only detected in BHSMW and BHSW by NMR, a flavonoid was isolated from fraction BHSM-A (Figure 1(a)). The low detection of this flavonoid was probably due to its low concentration in the analyzed sample.

In phytochemical prospecting for the detection of organic acids in shoot fractions of $U$. humidicola, only low intensity signals were detected in the ethyl acetate and butanol fractions (data not shown). In contrast with the NMR analysis, the presence of organic acids was detected in the hexane and dichloromethane fractions and in the ethyl acetate fraction, with low intensity for phytochemical 
prospecting and RMN analyses. Interestingly, although the presence of cinnamic derivatives was low in the butanol fraction, flavonoid presence was higher (data not shown), as detected by prospecting techniques and confirmed by NMR. This may indicate that the low presence of cinnamic derivatives be due to your use as biosynthetic precursors of flavonoids. The presence of phenolic compounds and flavonoids in plants is dynamic, and plants may direct their metabolism towards flavonoid synthesis at certain times, e.g., to attract pollinating insects during flowering or when in need of chemical defenses. At these times, the levels of phenolic acids may be greatly reduced, and they may not be detected, depending on the method used. This would explain the variations in flavonoid presence, in contrast to cinnamic acids, and supports the joint use of these techniques whenever possible. However, biological activity must also be considered, which, in this case, is associated with inhibition of germination.

The strong inhibition of L. sativa germination observed in response to extract BHSW agreed with previous reports, showing that water extracts may have high allelopathic potential, especially if they contain soluble phenolic acids [16]. Agreeing with this information, the CE electropherogram (BHSW) revealed the presence of phenolic compounds, although little pronounced (Figure 3), which may explain the inhibition of lettuce germination by these extracts.

In addition to phenols, a saponin mix with at least three components, including gitogenin derivatives, was identified in the roots of $U$. humidicola by ${ }^{1} \mathrm{H}$ NMR spectral analysis and comparison with published data of saponin from $\mathrm{Ba}$ lanitesaegyptica (Pettit et al. 1991), Figure 2. The presence of these compounds has several implications, such as animal toxicity, which has been associated previously with the presence of a saprophytic fungus (Pithomyceschartarum) in species of the genus Urochloa and is currently attributed to the presence of saponins in the leaves of Brachiaria species [23] [24] [25]. With special relevance for the present study, saponins also have allelopathicaction [26]. Thiswas indicated by the negative effects of the saponins isolated from the root extracts of $U$. humidicola on the germination of L. sativa and $M$. axillare compared to the control (Figure 9).

Terpenes are the largest class of secondary metabolites and include many volatile compounds with biological activity. In the present study, terpeneswere detected in extracts with high rates of germination inhibition. Steroids and triterpenes were detected in $\mathrm{BHSH}$ and $\mathrm{BHRH}$, with high intensity in both phytochemical prospecting and NMR (Table 1), and sitosterol and stigmasterol were identified in BHRH (Figure 1(b)). [27] attributed inhibitory effects on the germination of Vignaunguiculata to stigmasterol, $\beta$-sitosterol and the triterpenelupeol, isolated from shoots of Justiciaanselliana. This is in contrast with the present study, where the lowest inhibitory effect on $L$. sativa germination and no effect on $M$. axillare were observed for the germination assay with BHFH (Figure 5(a) and Figure 5(c)). This finding agrees with that of [28]. In contrast, BHRH resulted in $100 \%$ germination inhibition for both L. sativa and Stylosanthes (Figure 7(a) and Figure 7(b)). [11] also observed an inhibitory effect of 
$U$. humidicola hydrolate and decoction water on three tropical legume species and reported that substances such as terpenes may be related to allelopathic activity. A possible explanation for this is that not all terpenes and steroids have inhibitory effects on germination and may even have synergistic effects, depending on the mix.

A quite interesting response was observed for the treatment with both FM and TCA (FM + TCA). In this treatment, intermediate percentages of germination significantly lower than the control were observed, indicating antagonism between the two substances (Figure 8). The biological activity of a given mix of allelochemicals is due not only to the concentration of each of its components but also to the interaction between them [16]. The germination response was similar for the control and the flavonoid treatments. For $M$. axillare, germination rates typically associated with antagonism and synergism were observed in response to the application of solutions containing flavonoids and cinnamic acids, alone or in combination.

In the present case, the flavonoid mix functioned as an "anti-allelochemical" because the flavonoid mix resulted in a similar response to the control and was used at the same concentration as TCA. This trend in plant response may have different interpretations and implications for different areas of research. Among other functions, flavonoids are known to be involved in cell protection and preservation [29]. The present results indicate that flavonoids may favor germination or decrease the phytotoxic effects of TCA. However, further studies of their role in antioxidant defense mechanisms against allelochemicals are needed, as they may act as both antioxidants and pro-oxidants [30].

The positive response of $L$. sativa and $M$. axillare germination to flavonoids suggests that plant improvement studies should prioritize the selection of grasses with higher flavonoid biosynthesis, as this process uses cinnamic derivatives, which include the main secondary metabolites of $U$. humidicola identified as possessing allelopathic activity.

\section{Conclusions}

The combined use of physical methods such as ${ }^{1} \mathrm{H}$ NMR and phytochemical prospecting enabled confirmation of the presence of certain metabolites. Capillary electrophoresis was observed to be a better technique for the identification of phenolic compounds in crude extracts than phytochemical prospecting and NMR.

Saponins isolated from root extracts of $U$. humidicola presented high germination inhibition capacity. The most sensitive legume to crude shoot and root extracts of $U$. humidicola was Stylosanthes spp., and the most tolerant was $M$. axillare.

Flavonoids may be associated with protection mechanisms against allelochemicals in $U$. humidicola. Studies of intercropping improvement and compatibility may consider the use of forages with higher capacity for flavonoid biosynthesis, as this process uses cinnamic derivatives. 


\section{Acknowledgements}

The authors would like to acknowledge the CNPq, FAPEMAT and FAPERJ. Technical and financial support was provided by the Programa de Pós-Graduaçãoem Química (PPGQ) at Federal Rural University of Rio de Janeiro (UFRRJ) and Federal Institute of Education, Science and Technology of Mato Grosso (IFMT) Campus Sorriso.

\section{References}

[1] Jank, L., Barrios, S.C., Valle, C.B., Do Simeão, R.M. and Alves, G.F. (2014) The Value of Improved Pastures to Brazilian Beef Production. Crop and Pasture Science, 65, 1132-1137. https://doi.org/10.1071/CP13319

[2] Skonieski, F.R., Viégas, J., Bermudes, R.F., Nörnberg, J.L., Ziech, M.F., Costa, O.A.D. and Meinerz, G.R. (2011) Composição botânica e estrutural e valor nutricional de pastagens de azevém consorciadas. Revista Brasileira de Zootecnia, 40, 550-556. https://doi.org/10.1590/S1516-35982011000300012

[3] Martuscello, J.A., Jank, L., Gontijo Neto, M.M., Laura, V.A. and Cunha, D.N.F.V. (2009) Produção de gramíneas do gênero Brachiaria sob níveis de sombreamento. Revista Brasileira de Zootecnia, 38, 1183-1190. https://doi.org/10.1590/S1516-35982009000700004

[4] Deminicis, B.B., Abreu, J.B.R., Vieira, H.D. and Araújo, S.A.C. (2010) Brachiaria humidicola (Rendle) Schweick em diferentes idades de rebrota submetida a doses de nitrogênio e potássio. Ciência e Agrotecnologia, 34, 1116-1123. https://doi.org/10.1590/S1413-70542010000500006

[5] Souza, F.M., Lemos, B.J.M., Oliveira Jr., R.C., Magnabosco, C.U., Castro, L.M., Lopes, F.B. and Brunes, L.C. (2016) Introdução de leguminosas forrageiras, calagem e fosfatagem em pastagem degradada de Brachiariabrizantha. Revista Brasileira de Saúde e Produção Animal, 17, 355-364. https://doi.org/10.1590/S1519-99402016000300003

[6] Bhadoria, P.B.S. (2011) Allelopathy: A Natural Way towards Weed Management. Amer J Exp Agric., 1, 7-20.

[7] John, J. and Sarada, S. (2012) Role of Phenolics in Allelopathic Interactions. Allelopathy Journal, 29, 215-230.

[8] Oliveira, A.P.P., Pereira, S.R., Cândido, A.C.S., Laura, V.A. and Peres, M.T.L.P. (2016) Can Allelopathic Grasses Limit Seed Germination and Seedling Growth of Mutambo? A Test with Two Species of Brachiaria Grasses. Planta Daninha, 34 639-648. https://doi.org/10.1590/s0100-83582016340400003

[9] Reigosa, M., Gomes, A.S., Ferreira, A.G. and Borghetti, F. (2013) Allelopathic Research in Brazil. Acta Botânica Brasílica, 27, 629-646. https://doi.org/10.1590/S0102-33062013000400001

[10] Souza-Filho, A.P.S., Pereira, A.A.G. and Bayma, J.C. (2005) Aleloquímico produzido pela gramínea forrageira Brachiariahumidicola. Planta daninha, 23, 25-32. https://doi.org/10.1590/S0100-83582005000100004

[11] Ribeiro, R.C., Carvalho, M.G., Lopes, H.M., Rossiello, R.O.P. and Barbieri Jr., E. (2012) Allelopathic Activity of the Hydrolate and Water Decoction of Brachiaria humidicola (Rendle) Plant Parts on the Germination of Four Tropical Leguminous Species. ISRN Agronomy, 2012, 1-6. https://doi.org/10.5402/2012/838767

[12] Oliveira, D.R., Nepomuceno, D.D., Castro, R.N., Braz Filho, R. and Carvalho, M.G. 
(2017) Special Metabolites Isolated from Urochloa humidicola (Poaceae). Anais da Academia Brasileira de Ciências, 89, 789-797. https://doi.org/10.1590/0001-3765201720160126

[13] Roberts, M.J., Long, S.P., Tieszen, L.L. and Beadle, C.L. (1993) Measurement of Plant Biomass and Net Primary Production of Herbaceous Vegetation. In: Photosynthesis and Production in a Changing Environment: A Field and Laboratory Manual, Chapman \& Hall, UK, 1-21.

[14] Matos, F.J.A. (2009) Introdução a fitoquímica experimental. Edições UFC, Fortaleza.

[15] Santos, S., Moraes, M.L.L., Rezende, M.O.O. and Souza Filho, A.P.S. (2011) Potencial alelopático e identificação de compostos secundários em extratos de calopogônio (Calopogoniummucunoides) utilizando eletroforese capilar. Eclética Quimica Journal, 33, 51-68. https://doi.org/10.1590/S0100-46702011000200003

[16] Souza-Filho, A.P.S., Guilhon, G.M.S.P. and Santos, L.S. (2010) Metodologias empregadas em estudos de avaliação da atividade alelopática em condições de laboratório-Revisão crítica. Planta Daninha, 28, 689-697. https://doi.org/10.1590/S0100-83582010000300026

[17] Alves, M.C.S., Medeiros Filho, S., Innecco, R. and Torres, S.B. (2004) Allelopathy of Plant Volatile Extracts on Seed Germination and Radicle Length of Lettuce. Pesquisa Agropecuária Brasileira, 39, 1083-1086. https://doi.org/10.1590/S0100-204X2004001100005

[18] Vokou, D., Douvli, P., Blionis, G.J. and Halley, J.M. (2003) Effect of Monoterpenoids, Acting Alone or in Pairs, on Seed Germination and Subsequent Seedling Growth. Journal of Chemical Ecology, 29, 2281-2301. https://doi.org/10.1023/A:1026274430898

[19] SAS Institute (2002) Statistical Analysis System SAS/STAT Software Version 9.0. SAS Institute, Cary, NC.

[20] Mitrovic, M., Jaric, S., Djurdjevic, L., Karadžic, B., Gajic, G., Kostic, O., Oberan, L.J., Pavlovic, D., Pavlovic, M. and Pavlovic, P. (2012) Allelopathic and Environmental Implications of plant Phenolic Compounds. Allelopathy Journal, 29, 177-198.

[21] Thi, H.L., Zhou, H., Lin, C.H., Liu, S., Berezin, M.Y., Smeda, R.J. and Fritschi, F.B. (2017) Synthesis and Plant Growth Inhibitory Activity of N-Trans-Cinnamoyltyramine: Its Possible Inhibition Mechanisms and Biosynthesis Pathway. Journal of Plant Interactions, 12, 51-57. https://doi.org/10.1080/17429145.2016.1278050

[22] Souza-Filho, A.P.S., Trezzi, M.M. and Ioue, M.H. (2011) Sementes como fonte alternativa de substâncias químicas com atividade alelopática. Planta Daninha, 29, 709-716. https://doi.org/10.1590/S0100-83582011000300025

[23] Souza, R.I.C., Riet-Correa, F., Brum, K.B., Fernandes, C.E., Barbosa-Ferreira, M. and Lemos, R.A.A. (2010) Intoxicação por Brachiaria spp. em bovinos no Mato Grosso do Sul. Pesquisa Veterinária Brasileira, 30, 1033-1042.

[24] Tokarnia, C.H., Brito, M.F., Barbosa, J.D., Peixoto, P.V. and Döbereiner, J. (2012) Plantas tóxicas do Brasil para animais de produção. Editora Helianthus, Rio de Janeiro.

[25] Seixas, J.N., Pinto, C.A., Rodrigues, A, Tokarnia, C.H., França, T.N., Graca, F.A.S., Davila, M.S. and Peixoto, P.V. (2016) Estudo comparativo das intoxicações por Brachiaria spp. e Pithomyces chartarum em bovinos. Revista Brasileira de Medicina Veterinária, 38, 1-10.

[26] Grisi, P.U., Gualtieri, S.C.J., Ranal, M.A. and Santana, D.G. (2011) Efeito alelopático 
do fruto de Sapindus saponaria na germinação e na morfologia de plântulas daninhas e de hortaliças. Planta Daninha, 29, 311-322. https://doi.org/10.1590/S0100-83582011000200009

[27] Kpoviessi, S., Gbaguidi, F., Gbenou, J., Accrombessi, G., Haddad, M., Moudachirou, M. and Quetin-Leclercq, J. (2006) Allelopathic Effects on Cowpea (Vigna unguiculata (L.) Walp) Plant and Cytotoxic Activities of Sterols and Triterpenes Isolated from Justicia anselliana (NEES) T. Anders. Electronic Journal of Natural Sciences, 1, 12-19.

[28] Macías, F.A., Simonet, A.M. and Galindo, J.C.G. (1997) Bioactive Steroids and Triterpenes from Melilotus messanensis and Their Allelopathic Potential. Journal of Chemical Ecology, 23, 1781-1803.

https://doi.org/10.1023/B:JOEC.0000006451.19649.a0

[29] Amalesh, S., Gouranga, D. and Sanjoy, K.D. (2011) Roles of Flavonoids in Plants. Int J Pharm Sci Tech, 6, 12-35.

[30] Behling, E.B., Sendão, M.C., Francescato, H.D.C., Antunes, L.M.G. and Bianchi, M.L.P. (2004) Flavonoide quercetina: Aspectos gerais e ações biológicas. Alimentos e Nutrição, 15, 285-292. 